\title{
Multicultural Education for Cultivating Nationalism and Preventing Radicalism of Santri in Pesantren
}

\author{
Haris Supratno \\ Universitas Negeri Surabaya, Surabaya, Indonesia \\ Dedy Rahman Prehanto \\ Universitas Negeri Surabaya, Surabaya, Indonesia \\ Resdianto Permata Raharjo \\ Universitas Hasyim Asy'ari, Jombang, Indonesia
}

\begin{abstract}
Multicultural education is an educational model that aims to cultivate mutual respect, tolerance, and recognize the rights of others' existence regardless of ethnic, national, racial, social, cultural, and religious status, for cultivating nationalism in santri. So that, they have senses of love, pride, for defending Indonesia as their nation and state and for preventing radicalism of santri in Pesantren. Multicultural education model in East Java Pesantren has similar model that is integrated both in formal and non-formal education by using role models given by caregivers, Kyai, and ustadz and being educated in daily activities. Multicultural education through the inculcating of habits and models that are applied in Pesantren environment through non-formal education, such as obedience and respect for caregivers, Kyai, ustadz, and others; obligatory prayer and tahajjud prayer in congregation; reciting classical books together; greeting everyone; modest, polite, respect, and tolerant behavior; recognizing the rights and existence of others as well as respecting for differences of opinion, ethnicity, nation, social status, culture, and religion. Whereas, multicultural education model through formal education can be seen from the habit of respecting the teacher; greeting when they meet the teacher; greeting while kissing his hand; when the teacher is explaining they must listen, not talking each other or making jokes; and when asking the teacher, they use good language and polite .
\end{abstract}

Keywords: education, multicultural, radicalism, pesantren, and santri.

DOI: $10.7176 /$ RHSS/9-20-03

Publication date:October $31^{\text {st }} 2019$

\section{Introduction}

Pesantren is one of the oldest educational models in Indonesia that is existed before the national education system in Indonesia, even before the existence of Unitary State of the Republic of Indonesia. The model of Pesantren education is still able to live and survive among rapid technological development. In the era of Industrial Revolution 4.0. development, Pesantrens were still able to survive and adjust. However, there is very interesting phenomenon in Pesantren that should be noticed by its caregivers and the government, namely the problem of low quality of human resources, especially the quality of santri or Pesantren students. The quality Pesantren students must be noted seriously by Pesantren caretakers as well as the Central and Local Governments in order to improve the quality of santri, so that they are able to adjust to the development of the times, both through non-formal and formal education (Supratno dkk. 2019: 1; 2019: 736; Anjana, 2011: 306).

Multicultural education and entrepreneurship are solutions to overcome the low quality of santri in Pesantren. Multicultural education and entrepreneurship can be used for broadening their knowledge, instilling sense of nationalism, improving their quality and independence, so as preventing radicalism of santri in Pesantren. The problem of radicalism in Indonesia and the world are often associated with Islam. Pesantren as the basis of Islamic development often get the impression that are considered as center of radical education. Although, this opinion is not correct. Even based on the researches which have been done in Pesantren; they found none of teachings, thoughts, language speeches, and radicalism behavior of santri in Pesantren. (Supratno dkk., 2018: 28-29).

Education is a process of community empowerment that is very strategic in educating life of our nation and preparing quality and virtuous human resources. Multicultural and entrepreneurial education are solutions in Pesantren to improve the quality and independence of santri so that they can prepare skilled santri to face the AEC implementation. Hence, santri can fill opportunities of employment in various government agencies and the industrial world (Fatkuroji (2014: 2 dan 4; Supratno dkk., 2019: 737).

It is in accordance with the opinion of Fadli (2014: 3-4) that AEC is determined to create a single market and production base that is stable, prosperous, and competitive, so that AEC can be more fruitful. The existence of AEC agreement provides both opportunities and challenges that will be faced by Indonesia. One of them is the problem of educated and skilled labors. Therefore, the Government of Indonesia must deal seriously with labor issues in the context of preparing qualified workers, so that they are ready to fill the labor vacancy in this country, 
so as not to be filled by foreign workers.

According to Supriyaningsih (2012: 104), entrepreneurship education is education that applies principles and methodologies toward life skills for students through curriculum which is integrated with development of school and community environment, especially in the work fields or companies (http://journal of Economic Education 1 (2) 2012. 5 April 2016). Entrepreneurship education aims to instill the concept of entrepreneurship as science, to maintain entrepreneurial spirit, to make entrepreneurial planning, and to carry out entrepreneurship practice. (Murtini, 2011: 401) (http://journal.um.ac.id, 5 April 2016).

In order to face the ASEAN Economic Community, entrepreneurship education is both challenge and opportunity through formal education and non-formal education which plays crucial role in preparing workers who are ready to enter the world of formal and non-formal work, both domestic and abroad within the scope of ASEAN, to prevent the flood of skilled outsider workers (Nagel, 2015: 8; Fatkuroji (2014: 104).

Facing radicalism and terrorism that occurs in various parts of the world, for examples in Asia, the Middle East, America and Europe, The Western often associating it with Islam because the perpetrators are generally carried out by Moslems. This outlook became even stronger after bombing and collapse of the World Trade Center in New York on September 11, 2001, so that Islamophobia arises in the Western world (Kim, 2016: 345; Yusuff et.al.: 2012; Yusoff, 2010: 2327; Lauriola et.al., 2015:147). It has caused United States have strong desire to destroy the Arabs world, such as Iraq, Libya, Afghanistan, and Iran, and suspect every Moslem who enters to USA, especially those who have the correlation with Islam.

According to Soliman et al. (2016: 127) and Fedotova (2013: 334), radicalism and terrorism that often occur in Indonesia are generally related to injustice, inequality, dissatisfaction, and oppression of certain groups who feel treated unfairly and oppressed by the Government.

Radicalism in Indonesia must be prevented by persuasive and educative approach which is taken seriously by the Government so as not to lead to the disintegration of Indonesia and not to weaken the sense of Indonesian people nationalism. Many scientists and historians are worried about the dispute of political elites in Indonesia. Nationalism of political elites is running low so that it needs self-awareness and following the national movement figures who had passed away, in terms of their attitudes, behavior, and statesmanship (Kusumawardani dan Faturochman, 2004: 61).

Multicultural education can instill and strengthen nationalism. The core of nationalism lies in equality of rights, freedom, democracy, social justice, and achievement. Nationalism demands responsibility between the state and its people. The state can guarantee democracy, equal rights, equity, security, peace and social justice for the people. While the people must obey the rules of their country such as paying taxes, loving the nation, in this case is Indonesian homeland, and ready to defend the country from threats that come both from within the country and abroad. Multicultural Education can also prevent santri radicalism. If the spirit of santri nationalism is already strong, it will be able to prevent santri radicalism.

\section{Research Method}

This study is designed as qualitative method because the data are descriptive data, in the form of spoken language resulted from interviews with Pesantren caregivers and field observations at Pesantren. The object of this research is Pesantren in East Java, which includes large, medium and small category of Pesantren, so that multicultural education model found can reflect the multicultural education model of Pesantren in East Java. The findings of multicultural education model in East Java Pesantren will be able to serve as model for Indonesian Pesantren in general, because the majority of large and modern Pesantren are in East Java and in general the founders and carers of Pesantren in Indonesia are also from pesantren alumni in East Java, such as Tebuireng Pesantren, Rejoso Peteringan Pesantren, Mifbaul Ulum Pesantren, Lirboyo Kediri Pesantren, and Darussalam Ponorogo Pesantren. Data collection techniques by observation, interview, and recording. The data analysis technique uses descriptive by describing multicultural education models in Pesantren in East Java.

\section{Findings and Discussion}

According to Mu'in (2011:288) and (Tilaar, 2002: 41) education must be able to bring benefits to the community, including the provision of life skills and soft skills for people who take part in education as ability for students to face the challenges of living in society in the era of ASEAN Economic Community and the Industrial Revolution 4.0. Education must include aspect of knowledge, attitude, and skills. Attitude aspect is one of the most important factors to shape ethics, morals, and character to instill senses of nationalism and multiculturalism, so that they can live in society which are respectful, tolerant, and loving each other.

Multicultural education and student character are as an integral part of cultural education that can be carried out through family education, value education in schools as well as families and communities. Multicultural and character education plays an essential role as process of empowering multicultural and character education because they are formed since childhood so they are strongly influenced by family and environment (Mu'in, 2011: 297, Tilaar, 2002: 455; Chrisiana 2005: 83). 
Multicultural education is urgent to be implemented in Indonesia, which is currently experiencing a number of events that lead to disintegration of the nation and deterioration of ethics and morality of the community. It will cause national elites of Indonesia losing their identity as a religious, civilized, and dignified nation. While the educational tradition in Indonesia seems immature to implement character and multicultural education that can be used as assets to form young generation who have character and nationalism which rooted in the cultural and religious values of their nation (Mu'in, 2011: 297; Tilaar, 2002:455; Afandi (2011: 86); Putri (2011: 206). Especially, since the 2019 Presidential and Vice-President Election, the impact is still felt today. Even small events can cause riots that result in national disintegration, such as the events occurred in Malang and Surabaya, which can lead to riots in Papua.

Multicultural education in Pesantren can instill mutual respect, tolerance, respect for achievement, acknowledge and appreciate the success of others, respect others who are different religions, love peace and care of social problems. (Sucipto, 2013: 1); (http://ejurnal.unesa.ic.id. 5 April 2016); (Zulnuraini, 2012: 1) (http://jurnal. pgsd. untad.dot.com, 5 April 2016).

Pesantren are both non-formal and formal education institution which have strong cultural resilience and flexible education system that is able to adapt to every change and development of times. Pesantren is a model of community-based and multicultural education whose main purpose is educating students to understand, to practice Islamic teachings, and to have a sense of nationalism or patriotism, so as to prevent the behavior of radicalism and terrorism of thought, speech, and action.

This is in accordance with the research done by Supratno et.al., (2018: 29), that character education in East Java Pesantren can prevent verbal or action radicalism because santri are accustomed to speak well and politely to the caregiver, Kyai, ustadz, older people, as well as to fellow santri. Each activity is directed towards various religious and nonreligious activities, such as attending congregational prayers, reciting classical books, tahajjud prayers, religious studies, and participating in activities in school or campus, independent study, shared meals, and sleeping together in the place and time ruled by Pesantren. Every day activities of santri at the cottage are always under the supervision of student advisors; there is one student advisor for each room. While in formal school, they are always under the supervision of ustadz or teacher.

The multicultural education model in East Java Pesantren has a similar model, both are applied in non-formal and formal education, because caretakers of Pesantren are generally alumni of large Pesantren that are relatively old, such as the Pesantren Tebuireng Jombang, Pesantren Mambaul Ulum Tambak Beras Jombang, Pesantren Darul Ulum Jombang, Pesantren Lirboyo Kediri, and Pesantren Darusaalam Gontor Ponorogo. The alumni of those large Pesantren later established smaller Pesantren which bring the model of education concept in which he had been living.

The multicultural education model through non-formal education generally can be seen from the behavior of daily life in the cottage such as respect and obedience of santri to Kyai, ustadz, and caregiver. The multicultural education of santri also appeared when they met with teachers, lecturers, ustadz, scholars and caretakers of the cottage. The students are scrambling to shake hands with a gesture of bowing as a sign of respect and kissing their hand respectfully. This behavior shows the character of lofty respect for teachers, lecturers, ustadz, scholars, and caregivers which has become behavior in the daily lives of santri and even become santri characteristics. After all santri meet with caregivers, scholars, and ustadz, they must shake hands and kiss their hands as a sign of santri respect and obedience to them. Large and modern Pesantren generally implement non-formal and formal education systems, so that multicultural education models are also applied in non-formal and formal education.

The multicultural education model at Pesantren Sunan Drajat Lamongan also has similarities with the model of cultural education in other East Java Pesantren, through both non-formal and formal education. Pesantren Sunan Drajat was found by Sunan Drajat or Raden Qosim or Syarifuddin, the second son of Raden Ali Rahmatullah or Sunan Ampel. It has an attractive Pesantren vision, which can be translated "Becoming a Revolutionary Pesantren towards civil society, the successor of Wali Songo ideals, has a praiseworthy attitude, knowledgeable and responsible for religion, homeland, and the nation."

The multicultural education model through non-formal education can be seen from the examples of daily life carried out by caregivers, kiai, ustadz, and senior santri or coaches, in accordance with Rasulullah SAW did, like more examples of action, do not talk much, respect, and tolerance to all people, regardless of class, ethnicity, ancestry, age, social status, nation, culture and religion, speak politely to anyone gently, love everyone, and be compassionate to anyone. Through daily life civilization such as congregational prayers, respect and obedience to caregivers, Kyai, ustadz, queuing habits, and extracurricular activities of scouting, sports, and marching bands and placing santri in rooms according to school levels, not based on their origin and ethnicity.

Whereas multicultural education through formal education is pursued by instilling habits when they are attending the learning process in schools with mutual respect and tolerance among fellow students, respecting and obeying to school principals, teachers, and school staffs (Interviewed with Biarin Ahwarumi, on November 8, 2018, in Pesantren Sunan Drajat Lamongan).

The multicultural education model in Pesantren Langitan Tuban also has similarities with other Pesantren in 
East Java, through non-formal and formal education. This is can be said as one of the oldest Pesantren in East Java, which was founded by K.H. Muhammad Nur in 1852 M. The cottage has produced great and charismatic figures in Indonesia who later also established a large and very famous Pesantren in Indonesia, such as K.H. Kholil Bangkalan, K.H. Hasyim Asy'ari in Jombang, and K.H. Syamsul Arifin in Situbondo.

The main purpose of education at Pesantren Langitan Tuban is to foster santri into human who: (1) have extensive religious knowledge and are able to practice their knowledge, be willing to sacrifice, and strive to uphold Islamic religious law, (2) have a good personality and be devoted to Allah SWT and carry out his law, (3) have competent in religious matters and able to solve various problems that exist in society (Supratno, 2018: 101).

Multicultural education models through non-formal education through inculcating of culture in everyday life, such as:

1. Respect and obey the caregivers, kiai, and ustadz.

2. When they are walking and meet accidentally with caregivers and Kyai, they must stop to shake and kiss their hands.

3. When facing Kyai, they must choose the right time so as not to disturb Kyai.

4. Speak gently to anyone.

5. Arrange the schedule of cleaning the items in the room alternately or picket.

6. Community service work in every Friday for cleaning the environment in the hut.

7. Fardhu prayers in congregation five times a day.

8. Learn with a predetermined time.

9. Associating fellow santri, respect, tolerance, and helping each other.

10. Young and junior santri must respect senior santri and administrators who have taken care of all the needs of junior santri.

11. Senior santri had to help and guide junior santri. Junior santri should call Senior santri as 'Kakak' or 'Mas', as a form of practice to live in the community, so they can respect and love others, both older and younger.

12. Santri who come from various regions and ethnic groups are placed in one room, so that they can adapt each other, respect each other, be tolerant, love and help each other,.

13. Santri who come from various regions are placed in the same level, so that santri can interact and respect each other, be tolerant, love and help each other.

14. Through advice during the general study and studying the classical books, as human being and Muolems, they must respect each other, be tolerant, love and help each other as brotherhood.

Multicultural education through formal education is pursued through various ways:

1. Respecting the teacher because the teacher he teaches knowledge patiently and sincerely, only expecting the blessing of Allah SWT.

2. When visiting a teacher's house, you should not knock on the door, wait for the teacher to come out of the house or room, then shake and kiss his hand.

3. When meeting a teacher on the road, must stop, pay respect, say hello, shake and kiss hand.

4. Not making joke in the classroom, not talking while the teacher explaining. If there is not clear about what the teacher is explaining, ask nicely in polite language (Interviewed with K.H. Abdullah Habib Faqih, November 10, 2018 in Pesantren Langitan Tuban).

According to K.H. Salahudin Wahid, caregiver of Pesantren Tebuireng Jombang, multicultural education model in Pesantren Tebuireng Jombang is applied through habit or culture in daily life, such as not beating others, not annoying others, not insulting people who are different from Islam religion, may not speak harshly with others, pray in congregation, recite Holy Quran together, study the classical book, respect caregivers, scholars, Kyai, and coaches, speak politely to others, and through social service. Pesantren Tebuireng Jombang has the Social Organization of Pesantren Tebuireng (i.e. LSPT). Through LSPT, students are trained to work socially, help disadvantaged communities by paying tuition of their schools, provide scholarships to students who attend formal education from elementary to tertiary level (Interview on October 14, 2018, in Pesantren Tebuireng Jombang).

Multicultural education has been contained in the Rules of Order of Pesantren and School/Madrasah in surrounding area of Pesantren Tebuireng in Jombang, which applies in non-formal and formal education. In Chapter I, Article 7 is as follows: (1) Santri / students are obliged to have a moral mercy by reflecting a sincere, honesty, responsibility, hard work, and tasamuh, (2) Santri / students must obey and serve others (3) Santri / students must speak polite words (Yunus, et.al., 2017: 87).

Related to the obligations of students contained in the Rules of Order of Pesantren and School / Madrasah in surrounding area of Pesantren Tebuireng in Jombang, Chapter I, Article 8 as follows: (1) Santri / students must reciting Quran or takhassus as scheduled (2) Santri/ students must pray Maghrib, Isya', and Subuh congregation in the mosque (Yunus, et.al., 2017: 88).

The rules relating to the major violation of santri are stipulated in the Rules of Conduct for Pesantren and School / Madrasah in Pesantren Tebuireng in Jombang, Chapter I, Article 10 as follows: (1) Santri/students are 
prohibited from insulting, fighting against caregivers, teachers, administrators, and employees of Pesantren Tebuireng, (2) Santri/students are prohibited from stealing and threatening both money and goods, (3) Santri/students are prohibited from fighting and abuse, (4) Santri/students are prohibited from raising or mobilizing the masses for demonstrations (Yunus, et.al., 2017: 88).

The rules relating to the medium violation of santri being set out in the Rules of Order of Pesantren and School / Madrasah in surrounding area of Pesantren Tebuireng Jombang, Chapter I, Article 11 as follows: (1) Santri/students are prohibited from damaging the facilities and infrastructure of the cottage and school / madrasah, (2) Santri/students are prohibited from doing anything that endangers or harms themselves, others, or the environment, (3) Santri/students are prohibited from carrying and set firecrackers ( (Yunus, et.al., 2017: 90).

The rules relating to minor violations of students are stipulated in the Rules of Pesantren and School / Madrasah in Pesantren Tebuireng Jombang, Chapter I, Article 12 as follows: (1) Santri / students insult or humiliate friends, (2) Santri / students turn on the radio, tape recorder, and similar to them loudly when the congregation prayers, study hours, and break time, (3) Santri / students disturb the peace of others, (4) Santri / students speak, write, and draw that impolite contents (Yunus, et.al., 2017: 90).

This rules are applied in schools/madrasah so that santri are accustomed to do or leave something prohibited as stated in Pesantren Tebuireng Jombang as well as the density of santri events, when participating in non-formal activities or in school/Madrasah when attending formal education. It is multicultural model of education in Pesantren Tebuireng Jombang and also become mental revolutionary movement that can prevent santri radicalism, either ideological radicalism, thought, or action.

The multicultural education model through non-formal education is already regulated in the board rules that have been described above, either those which include major, medium or minor order and restriction. Activities that must be carried out, such as obedience and respect for Kyai, ustadz, and caregivers.

The rules described above applied to non-formal education both at Pesantren and when santri attend formal education in school or campus. Multicultural education model through formal education can be seen from:

1. Dhuha prayer in congregation. It is done every morning before entering class, santri who are students of schools are invited to do the dhuha prayer in congregation, which is led by the teachers in turn. Dhuha prayers in the formal education environment of Pesantren has become a culture for santri.

2. Obedience and respect for the teacher. Santri/students are instilled to be obedient and respectful to caregivers, scholars, and ustadz in daily life, both when attending non-formal education and formal education. Everyday when he meets his teacher, he has to greet, shake hands, and kiss the teacher's hand. The culture has become a daily sight and has become santri/students' culture each time.

3. Speaking kindly and politely to anyone. Santri/students when attending formal education are cultivated to speak well and they are accustomed to always speak good to anyone.

4. Santri / students are prohibited from speaking, writing and drawing impolite matters (Yunus, et.al., 2017: 90).

To broaden insight, knowledge, and strengthen multiculturalism and nationalism of caregivers, Kyai, ustadz, and santri, Pesantren Tebuireng Jombang often holds national and international seminars, either in the fields of education, social, economics, nationality, and technology. The themes are related to the role of pesantren education, national education, religious education, nationalism, entrepreneurship, and technology, by presenting national and international experts, community leaders, and state officials. On August 23-25, 2019, in the context of the 120th Anniversary of Pesantren Tebuireng Jombang, a national seminar was also held under the theme "National Seminar Combining National Education and Religious Education" by presenting the founder of pesantren, leaders of social organizations of Nadhatul Ulama and Muhammadiyah, Minister of Research, Technology, and Higher Education, Minister of National Education, and Minister of Religios Affair.

Pesantren Tebuireng Jombang is often visited by state officials, such as President, Ministers, Panglima, Kapolri, Pangdam and Kapolda. During each visit of state officials, lectures were also held to broaden the nationalism and multicultural perspectives of caregivers of Kyai, ustadz, santri, and were attended by various regional officials and community leaders.

According to K.H. Abdul Hadi, S.H. caretaker of Pesantren Madrasatul Qur'an Jombang, the multicultural education model at Pesantren Madrasatul Qur'an is almost the same as other Pesantren in East Java, namely through uswatun khasanah, instilling the values of caregivers, Kyai, and ustadz, and advice. The multicultural education model is also applied through the Pesantren's rule so that santri have character obedient to the rules set by the caretakers of Pesantren. These rules are outlined in The Handbook of Pesantren Madrasatul Qur'an santri.

According to Abdul Ghofur, multicultural education in Pesantren Madrasatul Qur'an includes the politeness and obedience of santri to caregivers, scholars, and ustadz, respect, and tolerant action among santri, and to the Kyai. This is reinforced by Ustadz Isa Ansori's opinion that advice given by the Kyai will become a guideline and be obeyed by santri, like Moslems who have a noble character or personality, life must respect and love one another. (Interview, on October 21, 2018, in Pesantren Madrasatul Qur'an).

The multicultural education model through non-formal education includes the willingness and obedience of 
santri, Kyai, ustadz, and caretakers of Pesantren. In any Pesantren, when santri meets teachers, lecturers, ustadz, religious scholars and caretakers of Pesantren, santri shakes hands with a gesture of bowing as a sign of respect and kisses hands. This behavior shows the character of respect for teachers, lecturers, Kyai, scholars, and caregivers is very high.

The multicultural education model through formal education especially the Tsanawiyah, Junior High School, High School, Aliyah, and Mualimin Education Levels has similarities, such as through joint dhuha prayers, congregational prayers, good and polite speech, mutual respect for fellow santri/students, principals, teachers / Kyai, and employee (Interview, on October 29, 2018 in Pesantren Madrasatul Qur'an Tebuireng Jombang).

\section{Conclusion}

Based on the description above, it can be concluded that the multicultural education model in East Java Pesantren has a similar model, which is integrated in non-formal and formal education, uses model done by caregivers, scholars, and ustadz and is cultivated in daily activities. The rules that exist in Pesantren or in non-formal education are also applied in formal education.

Multicultural education through non-formal education can be seen inculcating of habits and ideals that are applied in Pesantren environment, such as respect for caregivers, Kyai, and others, congregational prayers, tahajud prayers, study the classical book together, greetings anyone, humble, polite, tolerating, recognizing the rights and existence of others, and respecting differences of opinion, ethnicity, nationality, social status, culture, and religion.

Whereas multicultural education through formal education is pursued through instilling the habits of santri when attending formal education such as respecting and obeying the teacher; when meeting the teacher, they must stop, respect, say hello, shake and kiss hands; if in the classroom, when the teacher explains, santri must not make jokes and talk. When asking the teacher, they must use good and polite language.

\section{References}

Afandi, Rifki. 2011. “Integrasi Pendidikan Karakter dalam Pembelajaran IPS di Sekolah Dasar”. Pedagogia. Vol.1, No. 1, Desember, hlm 85-98 (http://jurnalunsida.ac.id. Diakses 19 April 2016).

A’la, Abd. 2006. Pembaruan Pesantren. Yogyakarta: Pustaka Pesantren.

Anjana, Atim R. 2011. Melodi Terakhir Sang Muazin Subuh. Banten; Shuhuf Media Insani.

Chrisiana, Wanda. 2005. "Upaya Penerapan Pendidikan Karakter Bagi Mahasiswa (Studi Kasus di Jurusan Teknik Industri Uk Petra)". Jurnal Teknik Industri vol.7. No.1. Juni. 83-90 (http://jurnal imdustri.petra.ac.ad. 19 April 2016).

Fadli, Muhammad. 2014. "Optimalisasi Kebijakan Ketenagakerjaan dalam Menghadapai Masyarakat Ekonomi ASEAN 2015”. Jurnal Rechts Vinding, Media Pembinaan Hukum Indonesia. Volume 3, nomor 2, Agustus. Hlm. 1-16 (http://rechtsvinding.bphn.go.id. 19 April 2016).

Fatkuroji. 2014. "Kesiapan Pendidik dan Tenaga Kependidikan dalam Menyosong Masyarakat Ekonomi ASEAN". Jurnal Idorah, Vol.1,Juni, hlm. 101-114 (http://jurnal.raden fatah.ac.id. diakses 19 April 2016).

Fedotova, Olga. 2013." Radicalism and Terrorism Problems in a Scientific Discourse of Rucian Social Sciences". Procedia Social and Behavioral Sciences 5(2010) 2119-2125. 334 -343.

Kim, Dae Soon. 2016. "The rice of European right radicalism: The case of Jobbik". Communist and PostCommunist Studies. 345-357.

Kusumawardani, Anggraeni dan Faturochman. 2004. "Nasionalisme". Buletin Psikologi, Tahun XII, No.2, Desember. 61.

Lay, Cornelis. 2006. "Nasionalisme dan Negara Bangsa", Jurnal Ilmu Sosial dan Ilmu Politik. Volume 10, Nomor 2, Nopember.165-180.

Lauriola, Marco, Renato Foschi, Luca Marchegiani. 2015. "Integrating values and cognitive style in model rightwing radicalism". Personality and Individual Differences. 147-153.

Mu'in, Fatchul. 2011. Pendidikan Karakter, Konstruksi Teoritik \& Praktik. Jakarta : Ar- Ruzz Media.

Murtini, Wiedy. 2011. "Pendidikan Kewirausahaan dengan Pemodelan Wirausaha". Jurnal Ilmu Pendidikan, Jilid 17,Nomor 5 Juni.hlm.401-410. (http:// journal.um.ac.id., diakses 19 April 2016).

Nagel, P.Julius F. 2014. "Peluang dan Tantangan UKM Indonesia Menghadapi Masyarakat Ekonomi ASEAN 2015”.hlm. 1-11 (http://jp.insoed.ac.id,diakses 19 April 2016)

Putri, Noviani Achmad. 2011. "Penanaman Nilai-Nilai Pendidikan Karakter Melalui Mata Pelajaran Sosiologi”.Jurnal Komunitas 32, 2005-2015 (http://journal.unnes.ac.id./nju/index.php/komunitas. diakses 19 April 2016).

Sucipto. 2013. "Model Pendidikan Karakter di SMA Negeri 1 Sidoarjo". Interaksi. Volume 01, Nomor 01. 1-7 (http://ejournal.unesa.ac.id. Diakses 19 April 2016).

Soliman, Abdrabo, Tarek Bellaj, Maher Khelifa. 2016. “An integrative psychologigal model for radicalism: Evidence from structural equation modeling". Personality and Individual Differences. 127-133.

Supratno, Haris dkk. 2015. Pendidikan Kesehatan Lingkungan Berbasis Pendidikan Karakter (Studi Kasus Pondok 
Pesantren se-Kabupaten Jombang). Surabaya: University Press.

Supratno, Haris dkk. 2018. Pendidikan Karakter Sebagai Media Pencegahan Radikalisme Santri di Pondok Pesantren. Surabaya: University Press.

Supratno, Haris, Heny Subandiyah, Resdianto Permata Raharjo. 2019. "Multicultual Education Model AS A Media To Prevent Radicalism Between Santri". Advances in Social Science Education and Humanities Research, Volume 335. Ist Internasional Conference on Education, Social Sciences and Humanities (ICESSHum 2019). 736.

Supriyatiningsih. 2012. "Penanaman Nilai-Nilai Kewirausahaan pada Siswa Melalui Praktik Kera Industri”.Jurnal of Economic Education 1 (2).hlm.103-109 (http://journal.unnes.ac.id/sju/index.php/jeec.diakses 19 April 2016).

Tilaar, H.A.R. 2002. Pendidikan untuk Masyarakat Indonesia Baru. Jakarta : Grasindo.

Yunus, 2017. Tatat tertib pesantren Tebuireng Jombang. Jombang: Tebuireng Jombang.

Yusof, Kamaruzaman, Iran Herman, Baddlihisham Mohd Nasir. 2010.”Islamic Radicalism in Malaysia: an overview”. Procedia Social and Behavioral Sciences 5(2010) 2119-2125.p. 2119-2125.

Yusof, Kamaruzaman, Iran Herman, Baddlihisham Mohd Nasir. 2010.’Islamic Radicalism in Malaysia: gender perspective". Procedia Social and Behavioral Sciences 5(2010) 2119-2125.p. 2326-2331.

Zulnuraini. 2012. "Pendidikan Karakter: Konsep, Implementasi dan Pengembangannya di Sekolah Dasar di Kota Palu”. Jurnal Dikdas, No 1, Vol. 1, September 2012. hlm. 1-10 (http://jurnal pgsd.untad.dot.com., diakses 19 April 2016) 